\title{
ミニシンポジウム記録 水産技術者の業務と技術者倫理
}

\section{6. 予測の可視化技術を用いた公衆との コミュニケーション（漁業と環境の視点から）}

岩見 聡 ${ }^{1}$, 関 達哉 ${ }^{2}$

1オリエンタルコンサルタンッ，2元 千葉県水産試験場

6. Communications with the public by means of visualization technique of forecast

(from the aspect of fishery and environment)

SATOSHI IWAMI ${ }^{1}$ AND TATSUYA SEKI ${ }^{2}$

${ }^{1}$ Oriental Consultants, Sibuya, Tokyo 151-0071, ${ }^{2} E x$-Chiba Prefectural Fisheries Experimental Station, Futtsu, Chiba 293-0042, Japan

\section{1. はじめに}

平成 22 年は生物多様年であり, 10 月には名古屋で 「生物多様性条約第 10 回締約国会議」(COP10) が開催 される。本年 3 月に閣議決定された「生物多様性国家

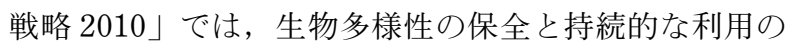
ため, 「里海」の保全, 再生が施策として位置づけられ, その担い手となる漁業者と市民との連携が重要になって いる。予測の可視化技術は里海の将来像を共有するな ぞ，漁業者と市民の間のコミュニケーションを図る上 で，有効なツールになり得ると考えられる。ここでは， 千葉県三番瀬の再生に向けての事例を紹介し，その可能 性の一端を示した。

\section{2. 三番瀬問題の概要}

三番瀬は東京湾奥部に残された唯一の干潟であり，区 画漁業権と共同漁業権が設定され，のり養殖業，貝類漁 業等が営まれている。当該海域では，平成 4 年〜 5 年に 埋立計画が，平成 11 年には埋立面積を大幅に縮小した 見直し計画が策定，公表されたが，平成 13 年に白紙撤 回された。

その後, 三番瀬の保全, 再生に関する「円卓会議」等 での議論を経て, 平成 18 年に再生計画が公表された。 「円卓会議」は行政，市民等が公開の場で三番瀬の保全， 再生について協議した画期的な場であったが，漁業補償 問題で, 漁業者が本格的に参画しなかったという課題も 有していた。

\section{3. 漁業者の取り組み}

三番瀬は周辺海域の埋立から残された海域であり, 漁 場の生産性を左右する潮通しが悪く, 厳しい漁場環境で あった。そこで, 南行徳漁業協同組合並びに市川市行徳 漁業協同組合は, 平成 8 年に「千葉北部漁場修復協議 会」を編成し，傘下に有識者からなる専門委員会を設置
して, 周辺海域の埋立による三番瀬の漁場環境への影響 を検討し，漁場計画に反映させる等の対策を講じた。

平成 11 年に公表された見直し計画に対しては埋立面 積の縮小が漁場環境にどのような回復効果を及ぼすか, 「海水交換シミュレーション」を実施し，見直し計画の 問題点を明らかにした上で, 潮通し（海水交換）を確保 するための「望ましい水際線」を設定した。

一連の検討結果は, 平成 14 年に南行徳漁業協同組合 と市川市漁業協同組合より千葉県知事に提出された。

\section{4. 可視化の事例}

千葉北部漁場修復協議会で実施された海水交換シミュ レーションは仮想的な粒子を浮かべて, 流れに伴う移動 を追跡するものである。見直し計画を含む複数の埋立 ケースで, 漁場内に粒子を配置して移動を追跡し, 漁場 に残留する粒子の数から海水交換率を求めている。ま た, 現況の地形と昭和 40 年代の地形での計算も行い, 三番瀬周辺の埋立の影響も検討している。シミュレーシ ョン結果はアニメーション化し, 分かりやすいものとし ている。

地形 : 現況は, 三番瀬周辺地区で埋め立てが行われて いるほか, 地盤沈下や市川・船橋の両航路の造成, 埋立 用材の採取跡等があり複雑な地形となっている。埋立前 は，干潟・浅場が広がりなだらかな地形となっている。

上げ潮最大時の流速分布 : 現況は $5 \mathrm{~cm} / \mathrm{s}$ 程度で北西 側奥部の流れが弱い。埋立前は $5 \sim 50 \mathrm{~cm} / \mathrm{s}$ 程度で広い 干潟・浅場で多様な流れが形成されている。

水温分布 : 現況は市川航路で下層水が湧昇している。 埋立前は水深が浅く漁場全体で泠えやすいことが分かる。

海水交換（その1）: 現況々昭和 40 年（三番瀬周辺で 埋立が行われる以前）の地形を再現し，のり養殖場内に 仮想的な粒子を配置して，一定期間が経過した後にのり 養殖場に残留する粒子の数から海水交換を評価した。

海水交換（その 2)：現況と昭和 40 年の地形に抢い て, 江戸川放水路からの出水時の塩分低下と出水後の回 復状況を再現した。江戸川放水路から仮想粒子（塩分は 時々刻々変化する）を流入させて, 河川水と海水との混 合と流れの変化を分かりやすく可視化した。

\section{5. おわりに}

千葉北部漁場修復協議会が実施した「望ましい水際線」 に関するシミュレーション結果については, 自然保護団 体等より三番瀬の埋立を容認したものとの批判がなされ たが，里海の保全，再生を「漁場環境の保全，再生」の 観点から発信したという意義を有すると考えられる。 